\title{
Karyology and nuclear DNA quantification of four species of Chaetomorpha (Cladophorales, Chlorophyta) from the western Atlantic
}

\author{
Todd K. Hinson \& Donald F. Kapraun \\ Department of Biological Sciences, University of North Carolina; Wilmington, \\ North Carolina 28403, USA
}

\begin{abstract}
Chromosome numbers are given for four species of Chaetomorpha from the warm temperate and tropical western Atlantic. The basic chromosome number is six, with three median and three submedian chromosomes. Chaetomorpha species represent a polyploid series, with numbers of 12,18 and 24 found in the present study. Microspectrophotometry data for each species were quantified by reference to standards with known DNA contents. Results indicate similar $2 \mathrm{X}$ $=1 \mathrm{C}=12$ genome sizes for $C$. aerea $(0.20 \mathrm{pg})$ and $C$. brachygona $(0.26 \mathrm{pg})$, and for $C$. antennina $(0.53 \mathrm{pg})$ and $C$. melagonium $(0.58 \mathrm{pg})$. These findings are compared with karyological features of Cladophora species to characterize the karyology of the cladophoralean genome.
\end{abstract}

\section{INTRODUCTION}

Members of the genus Chaetomorpha (Chlorophyta, Cladophorales), with their relatively large chromosomes and synchronous nuclear divisions, have been the subject of numerous cytogenetic studies (Sarma, 1983). Chromosome numbers reported for various taxa range from $\mathrm{N}=12$ to $\mathrm{N}=36$, with $2 \mathrm{X}=12$ to $4 \mathrm{X}=24$ being most common (Sinha, 1967; Sarma, 1983). Species apparently represent a polyploid series in which the basic chromosome complement is $\mathrm{X}=6$.

In the closely related genus Cladophora (Olsen-Stojkovich et al., 1986; Kapraun \& Breden, 1988), species show an unusual uniformity of chromosome numbers, with differences in chromosome size resulting in the karyotype complement of one species appearing to be a reduced or enlarged version of that of another (Kapraun \& Gargiulo, $1987 \mathrm{a}, 1987 \mathrm{~b})$. These six basic chromosomes include three with median centromeres and three with sub-median ones (Wik-Sjöstedt, 1970). Analysis of seven Cladophora species indicated correlations between karyotype pattern/chromosome (genome) size and plant morphology, habitat specificity and phytogeography (Kapraun \& Gargiulo, 1987a, $1987 b$ ). Furthermore, estimates of the basic genome (1X) for these Cladophora species indicated large-scale, discontinuous variation in their nuclear DNA content.

It is not known to what extent these generalizations apply to species of Chaetomorpha, as published karyological reports are limited to chromosome numbers. Consequently, the present cytogenetic investigation was initiated on four Chaetomorpha species from the warm temperate and tropical western Atlantic to provide details on their 
chromosome sizes and karyotypes. In addition, cytophotometry was used to estimate the haploid $(2 \mathrm{X}=1 \mathrm{C}=12)$ genome size of these species to determine patterns of interspecific DNA variation.

\section{MATERIALS AND METHODS}

\section{Source of specimens}

Two Chaetomorpha species were collected from North Carolina sites: $C$. aerea (Dillw.) Kütz. from Kure Beach, and C. melagonium (Weber et Mohr) Kütz. from Ft. Macon. Chaetomorpha brachygona Harvey specimens were obtained from Ft. Pierce, Florida, and C. antennina (Bory) Kütz. was collected from South Point, Barbados.

\section{Fixation and karyotype analysis}

Specimens were fixed in the laboratory at $24: 00$ in 3:1 absolute ethanol-glacial acetic acid, left overnight, and transferred to $70 \%$ ethanol for storage (Kapraun \& Martin, 1987). Aceto-orcein staining procedures used for the karyological study have been previously described (Kapraun \& Gargiulo, 1987a). Documentation by photomicrographs was provided by an Olympus BH2-RFK fluorescence microscope. Karyotypes were prepared by viewing $35 \mathrm{~mm}$ Kodak Plus-X negatives with a $48 \mathrm{X}$ microfiche reader and tracing the projected images (Kapraun \& Freshwater, 1987).

\section{Determination of nuclear DNA-content}

Fixed material for measurement of nuclear DNA was prepared as follows. Chaetomorpha filaments were transferred from alcohol and soaked in distilled water for 1-3 $\mathrm{h}$ to soften material. Filaments were then macerated using ground glass slides to disrupt cells and liberate nuclei from the cytoplasm. Ground material was rinsed onto coverslips coated with Subbing solution $10.1 \mathrm{~g}$ gelatin, $0.01 \mathrm{~g}$ chrome alum in $100 \mathrm{ml}$ water), and allowed to dry at $40^{\circ} \mathrm{C}$ to evaporate all residual alcohol. Coverslips were soaked in phosphate buffer solution (PBS) for $1 \mathrm{~h}$, stained with hydroethidine for 1-2 mins, and allowed to destain in PBS overnight (Kapraun \& Bailey, 1989).

Data were standardized to the fluorescence values $\left(\mathrm{I}_{\mathrm{f}}\right)$ of the hydroethidine-stained angiosperm Antirrhinum majus L. with a 2C nuclear DNA content of $3.2 \mathrm{pg}$ (Bennett \& Smith, 1976) and Cladophora albida (Huds.) Kütz. (Cladophorales, Chlorophyta) with 2C $=0.8$ pg DNA (Bot et al. 1989a; Kapraun \& Dutcher, 1991). Angiosperm seeds were germinated in Petri dishes lined with filter paper moistened with distilled water. Root tips $1 \mathrm{~cm}$ long with abundant root hairs were collected, fixed and stained. Chromosome counts from root tip meristems were made to confirm the ploidy level of the cultivar (Bennett \& Smith, 1976). Zoospores of $C$. albida released in culture readily settled on coverslips, facilitating fixation and staining.

Observations and photomicrographic documentation were made with brightfield and epi (incident) UV illumination using the above microscope and exciter filter BP-545, dichroic mirror DM-580 and barrier filter O-590 which are specific for hydroethidine emissions (Kapraun et al., 1988). A microphotometer (Kinetek Photometry Systems) equipped with a rotating nosepiece housing an array of perforated diaphragms permitted 
selection of pinhole apertures corresponding to the diameter of the nucleus being viewed. Consequently, error from cytoplasmic (extranuclear) fluorescence was greatly reduced (Kapraun \& Shipley, 1990). Fluorescence data were analysed and presented in histograms (Goff \& Coleman, 1984) to demonstrate the $I_{f}$ peaks associated with $2 \mathrm{C}$ and $4 \mathrm{C}$ nuclei.

\section{RESULTS}

\section{Identification of specimens}

Comparative cytogenetic investigations are of limited value unless accurate determinations can be made for the included taxa. Chaetomorpha species pose formidable systematics problems due to the morphological plasticity of the genus and the small number of characters considered to have taxonomic significance. Determinations for this investigation follow Blair's (1983) monographic treatment for NE America and are based primarily on cell diameter and length/width ratios, growth habit, and basal cell size (Table 1). Two pairs of superficially similar Chaetomorpha species were included in this study.

Table 1. Cell dimensions in four species of Chaetomorpha

\begin{tabular}{|c|c|c|c|c|c|c|}
\hline & \multicolumn{2}{|c|}{ Cell diameter $(\mu \mathrm{m})$} & \multicolumn{2}{|c|}{ Filament cell L:W } & \multicolumn{2}{|c|}{ Basal cell $\mathbf{L}: W$} \\
\hline & Reported * & Observed & Reported " & Observed & Reported* & Observed \\
\hline C. brachygona & $80-150$ & 55 & $1.0-1.3$ & 1.3 & - & - \\
\hline C. aerea & $125-400$ & $80-90$ & $1.5-2.5$ & $0.9-2.4$ & $3-8$ & $6-7$ \\
\hline C. melagonium & $350-750$ & 440 & $1.0-2.0$ & 0.7 & $8-14$ & 9 \\
\hline C. antennina & $450-550$ & $420-540$ & $2.0-4.0$ & $1.5-2.5$ & $8-12$ & 7 \\
\hline \multicolumn{7}{|c|}{ - Taylor (1960), Blair (1983) } \\
\hline
\end{tabular}

C. brachygona Harvey and C. aerea (Dillw.) Kütz. are both relatively small, delicate plants (Figs 1 and 2). C. brachygona filaments are typically 80-150 $\mu \mathrm{m}$ diam, and grow in unattached, entangled masses with few basal cells. C. aerea filaments are thicker (Table 1), and grow in erect tufts attached to the substratum by small basal cells (Blair, 1983). C. melagonium (Weber et Mohr) Kütz. and C. antennina (Bory) Kütz. (=C. media [C. ag.] Kütz, Wynne 1986) are both large, coarse plants (Figs 3 and 4), with filament diameters of 350-750 $\mu \mathrm{m}$ and $450-550 \mu \mathrm{m}$, respectively (Table 1). C. melagonium has plate-like cells $(\mathrm{L}: \mathrm{W}=1-2)$ while $C$. antennina has subquadrate cells (Figs 3 and 4 ). In culture, $C$. melagonium produced multicellular, uniseriate filaments (Fig. 5) within 10-14 days of zoospore attachment, while $C$. antennina zoospores germinated into multinucleate, clavate germlings (Fig. 6) which remained unicellular for up to 8 weeks. 

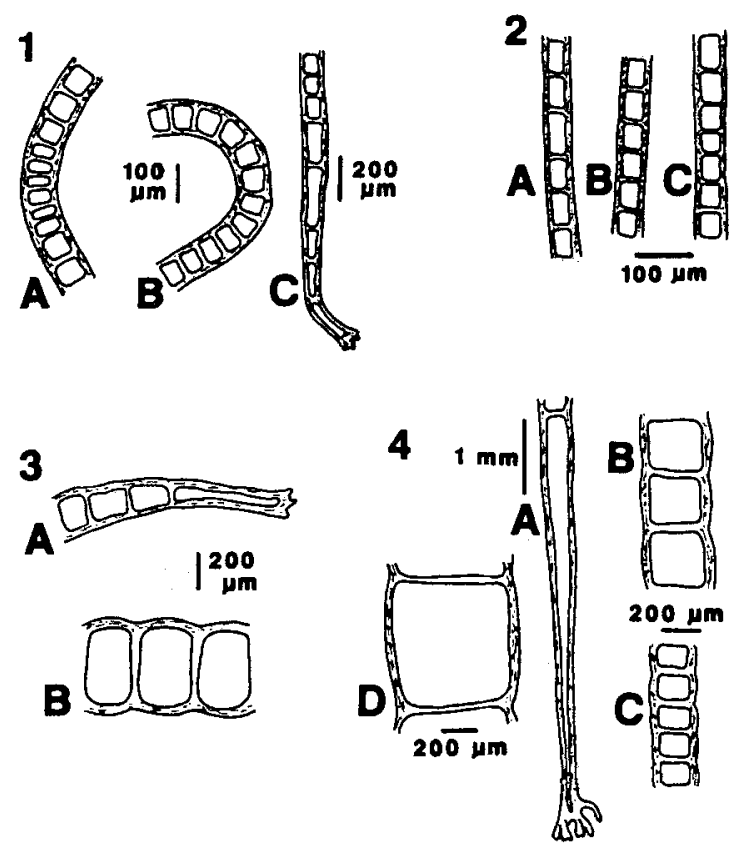

Figs 1-4. Morphology of Chaetomorpha specimens collected in nature

Fig. 1. Chaetomorpha aerea. A: erect filament with intercalary divisions; B: subquadrate cells in apical region of erect filament; $C$ : basal region of filament and basal cell

Fig. 2. C. brachygona. A-C: filaments showing length: width $(\mathrm{L}: \mathrm{W})$ variation in vegetative cells Fig. 3. C. melagonium. A: basal region of filament and basal cell; B: characteristic platelike vegetative cells

Fig. 4. C. antennina. A: basal cell; B \& C: filaments showing $L: W$ variation of vegetative cells; $D$ : characteristic subquadrate vegetative cells

\section{Karyology}

In Chaetomorpha antennina and $C$. melagonium, interphase nuclei had similar diameters of 4-6 $\mu \mathrm{m}$. Chaetomorpha brachygona and $C$. aerea had substantially smaller interphase nuclei (3-5 $\mu \mathrm{m}$ diam). The presence of highly stained chromocenters associated with nuclei in both of the former species (Fig. 7), and their absence in the latter (Fig. 8), suggests a positive correlation between heterochromatin and genome size (Sarma, 1983; Wik-Sjöstedt \& Nordquist, 1970; Kapraun \& Gargiulo, 1987a).

Nuclear divisions in the Chaetomorpha species investigated were synchronous, and often large numbers of contiguous cells were found with nuclei in some stage of division (Fig. 9). Chromosome numbers for the four Chaetomorpha species in the present study are given in Table 2. Apparently, this is the first published report of karyological data for C. brachygona. Despite their similar filament diameters, C. aerea and C. brachygona can be readily distinguished by their characteristic karyotypes. Chaetomorpha aerea has relatively small chromosomes $(0.5-1.0 \mu \mathrm{m})$, with little distinction in size between the largest and smallest (Fig.10). Chaetomorpha brachygona chromosomes range from 

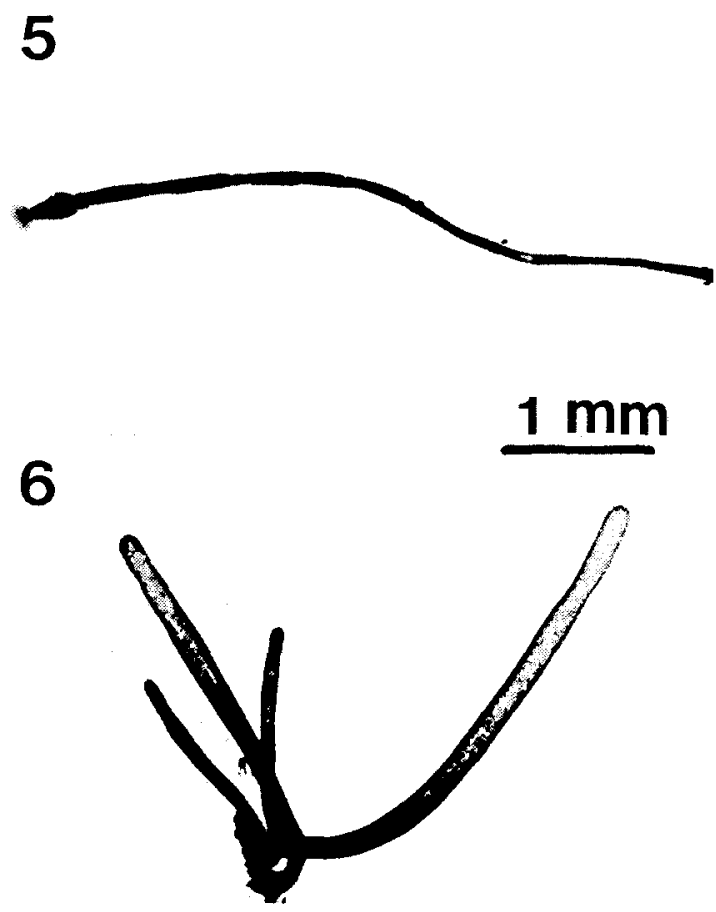

Figs 5 and 6. Germling development in culture

Fig. 5. Chaetomorpha melagonium 10-day old germlings

Fig. 6. C. antennina 8-week old germlings

Table 2. List of chromosome numbers reported in Chaetomorpha

\begin{tabular}{|c|c|c|c|c|}
\hline \multirow[t]{2}{*}{ Species } & \multicolumn{3}{|c|}{ Chromosome number } & \\
\hline & $2 \mathrm{X}$ & $3 \mathrm{X}$ & $4 \mathrm{X}$ & \\
\hline Chaetomorpha aerea (Dillw.) Kütz. & 12 & & 24 & Patel (1971) \\
\hline C. aerea (Dillw.) Kütz. & & 18 & & Sinha (1958) \\
\hline C. aerea (Dillw.) Kütz. & 10 & & 20 & Hartmann (1929) \\
\hline C. aerea (Dillw.) Kütz. & 12 & & & Kornmann (1968) \\
\hline C. aerea (Dillw.) Kütz. & 12 & & 24 & Present study \\
\hline C. antennina (Bory) Kütz. & & 18 & 24 & Present study \\
\hline C. antennina (Bory) Kütz. & & $17-18$ & & Bodenbender \& Schnetter (1990) \\
\hline C. brachygona Harvey & 12 & & 24 & Present study \\
\hline C. melagonium (Web. \& Mohr.) Kütz. & 12 & & 24 & Patel (1971) \\
\hline C. melagoniurn (Web. \& Mohr.) Kütz. & 12 & & 24 & Bodenbender \& Schnetter (1990) \\
\hline C. melagonium (Web. \& Mohr.) Kütz. & & 18 & & Sinha (1958) \\
\hline C. melagonium (Web. \& Mohr.) Kütz. & & 18 & & Present study \\
\hline
\end{tabular}

0.6-1.5 $\mu \mathrm{m}$ long (Fig. 11). Although centromeric regions could not be distinguished with certainty, presence of straight and curved chromosomes suggests submedian and median centromeres, respectively (Kapraun \& Gargiulo, 1987a). 


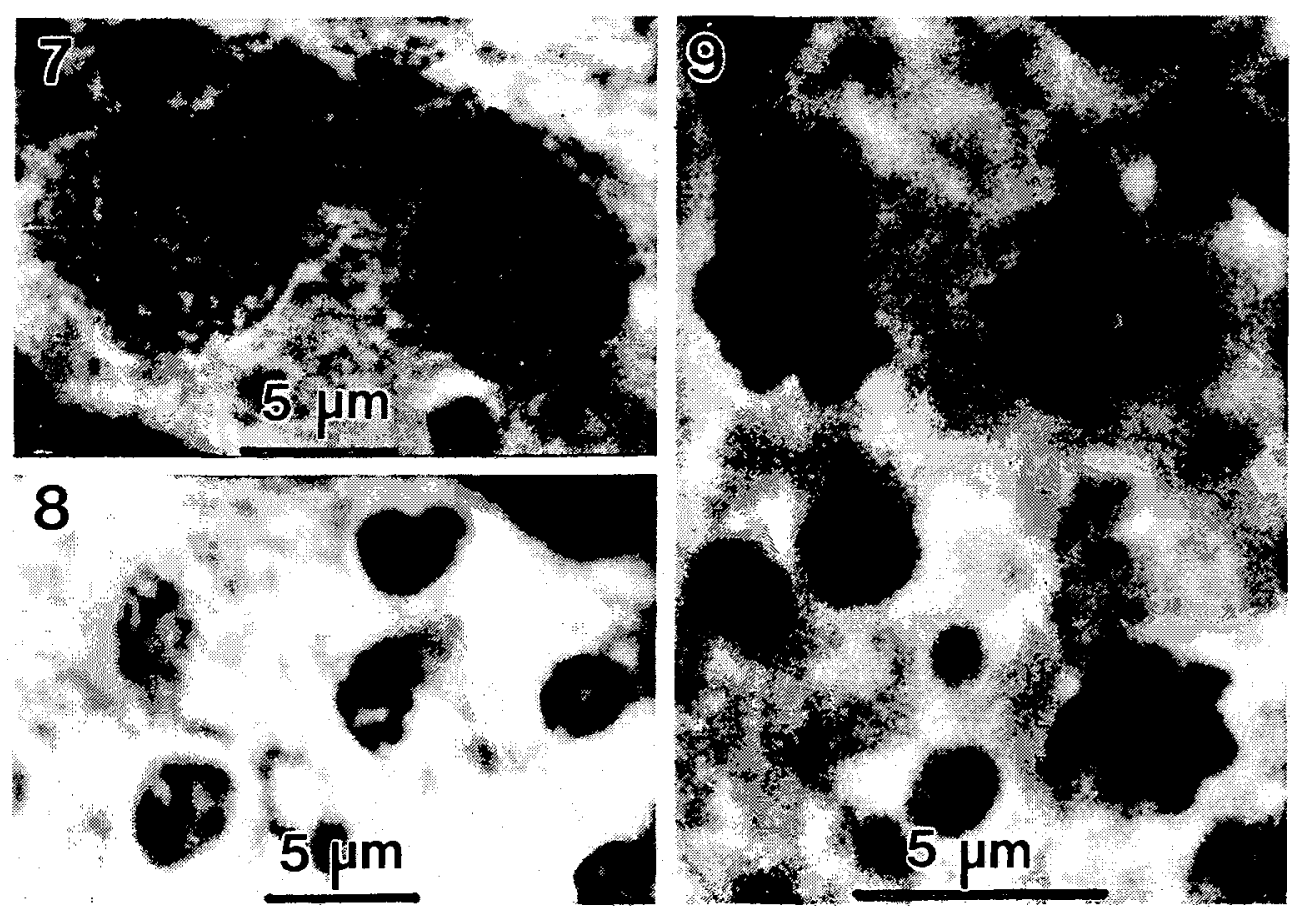

Figs 7-13. Chaetomorpha nuclei after aceto-orcein staining

Fig.7. C. antennina nuclei with extensive dense heterochromatic regions

Fig. 8. C. aerea with diffuse heterochromatic regions

Fig. 9. C. aerea with synchronous mitotic divisions in $4 \mathrm{X}=24$ nuclei

The species pair characterized by large-diameter filaments was found to have similar karyotypes. Both $C$. antennina and $C$. melagonium have chromosomes ranging from $0.8-1.8 \mu \mathrm{m}$ long (Figs 12 and 13), with the longest showing clear evidence of submedian centromeric regions. Presence of equal numbers of straight and curved chromosomes suggests an equal distribution of submedian and median centromeres in both of these species.

\section{DNA cytofluorometry}

Microspectrophotometry with DNA-localizing fluorochromes has been used previously for quantification of nuclear DNA in coenocytic algae (Kapraun et al., 1988; Calderón-Saenz \& Schnetter, 1989). In the present study, hydroethidine staining for periods as brief as $1 \mathrm{~min}$ followed by $12-24 \mathrm{~h}$ destaining at $4^{\circ} \mathrm{C}$ resulted in intense nuclear fluorescence.

$\mathrm{I}_{\mathrm{f}}$ values for the angiosperm Antirrhinum majus and the marine alga Cladophora albida (Fig. 14) were plotted against their known DNA contents to derive a standard line (Kapraun \& Shipley, 1990). In a typical series of observations, the ratio of their $2 \mathrm{C}_{\mathrm{f}}$ values $(62: 18=3.4)$ was found to closely approximate the ratio of their reported $2 \mathrm{C}$ DNA $(\mathrm{pg})$ contents $(3.2: 0.8=4.0)$ (Fig. 15). 

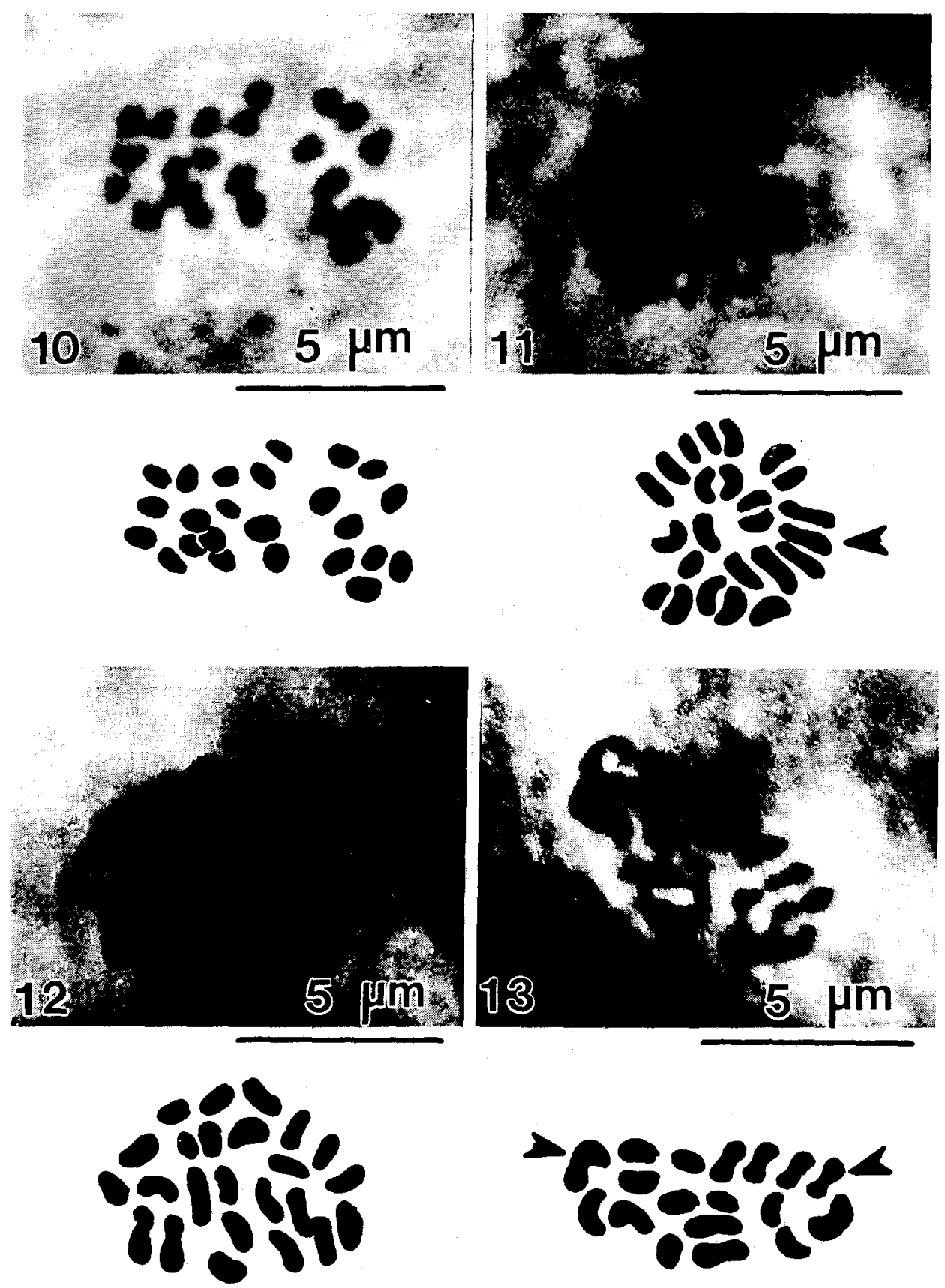

Fig. 10. C. aerea late prophase mitotic nucleus with $4 \mathrm{X}=24$ chromosomes

Fig. 11. C. brachygona late prophase mitotic nucleus with $4 \mathrm{X}=24$ chromosomes. Arrow indicates pairing of homologous chromosomes

Fig. 12. C. antennina late prophase mitotic nucleus with $4 \mathrm{X}=24$ chromosomes

Fig. 13. C. melagonium late prophase mitotic nucleus with $3 \mathrm{X}=18$ chromosomes. Arrows indicate submedian centromeric regions 

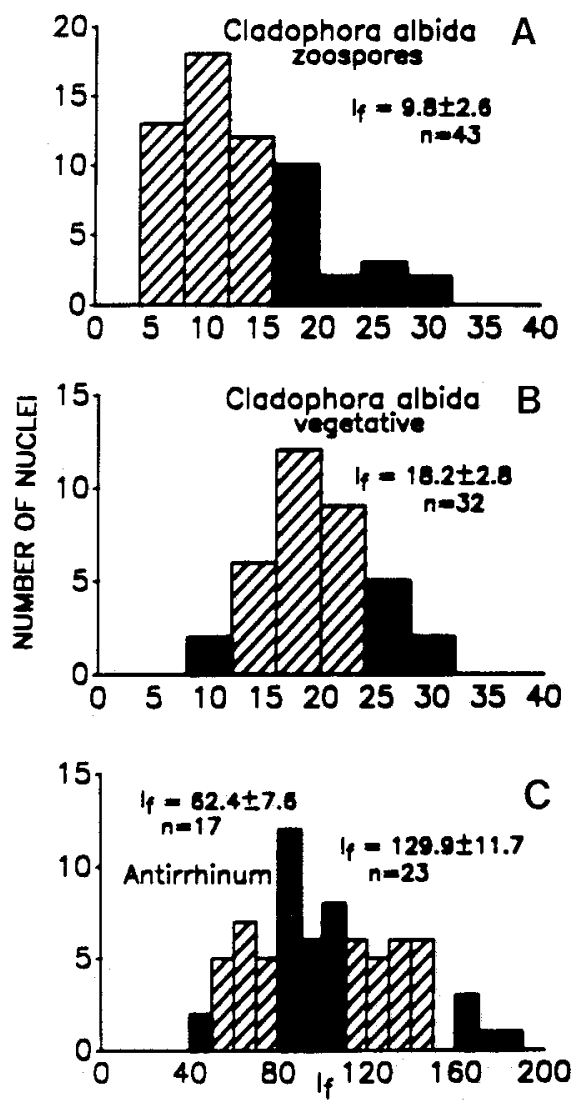

Fig. 14. Comparison of frequency distributions of relative DNA values for nuclei after hydroethidine staining in (A) Cladophora albida zoospores and (B) vegetative cells, and (C) Antirrhinum majus. $\mathrm{n}=$ number of nuclei, indicated by cross-hatching, used to calculate C-levels (Kapraun \& Shipley, 1990); $I_{\mathrm{f}}=$ fluorescence intensity mean $\pm \mathrm{SD}$

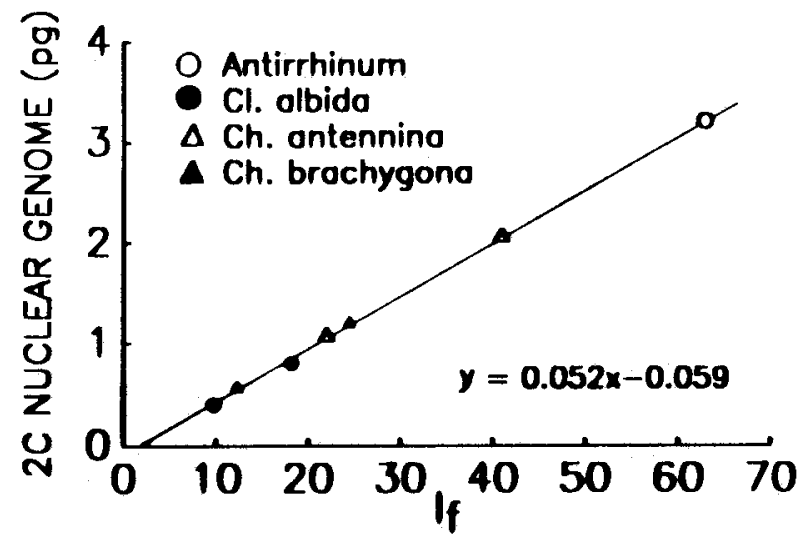

Fig. 15. $\mathrm{I}_{\mathrm{f}}$ values for $1 \mathrm{C}$ and $2 \mathrm{C}$ nuclei in Cladophora albida and $2 \mathrm{C}$ nuclei in Antirrhinum majus plotted against their known DNA contents (Bot et al., 1989b; Bennett \& Smith, 1976) to derive a standard line. DNA contents for Chaetomorpha antennina and C. brachygona $1 \mathrm{C}$ and $2 \mathrm{C}$ nuclei are extrapolated from their $\mathrm{I}_{\mathrm{f}}$ values. Data standardized to mean $\mathrm{I}_{\mathrm{f}}$ values of $2 \mathrm{C}$ nuclei in $A$. majus 


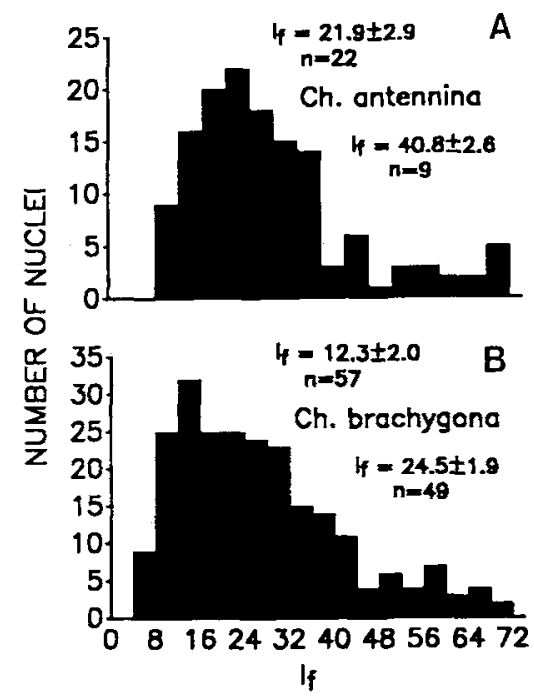

Fig. 16. Comparison of typical frequency distributions of relative DNA values for 2C and 4C nuclei $(4 \mathrm{X}=24)$ in Chaetomorpha antennina and $C$. brachygona after hydroethidine staining. See Fig. 14 legend symbois for explanation

Table 3. DNA contents determined for four species of Chaetomorpha and their estimated 2-C level $(2 \mathrm{X}=2 \mathrm{~N}=12)$ genomes $(\mathrm{pg})$

\begin{tabular}{|c|c|c|c|c|c|}
\hline & \multicolumn{4}{|c|}{$\begin{array}{c}\text { DNA contents }(\mathrm{pg}) \\
\text { determined for isolates }\end{array}$} & \multirow{3}{*}{$\begin{array}{l}\text { Extrapolated DNA } \\
\text { contents (pg) for } \\
2 \mathrm{C} \text {-level genomes } \\
2 \mathrm{X}=2 \mathrm{~N}=12\end{array}$} \\
\hline & \multicolumn{2}{|c|}{$3 \mathrm{X}$} & \multicolumn{2}{|c|}{$4 X$} & \\
\hline & $2 \mathrm{C}$ & $4 \mathrm{C}$ & $2 \mathrm{C}$ & $4 \mathrm{C}$ & \\
\hline \multirow{7}{*}{$\begin{array}{l}\text { C. aerea } \\
\mathrm{n}=24\end{array}$} & & & 0.33 & & 0.17 \\
\hline & & & 0.36 & & 0.18 \\
\hline & & & 0.37 & & 0.19 \\
\hline & & & & 0.93 & 0.23 \\
\hline & & & & 0.75 & 0.19 \\
\hline & & & & 0.83 & 0.21 \\
\hline & & & & & $\bar{X}=0.20 \pm 0.02$ \\
\hline \multirow{5}{*}{$\begin{array}{l}\text { C. antennina } \\
n=24\end{array}$} & & & 0.98 & & 0.49 \\
\hline & & & 1.08 & & 0.54 \\
\hline & & & & 2.16 & 0.54 \\
\hline & & & & 2.07 & 0.52 \\
\hline & & & & & $\bar{X}=0.53 \pm 0.02$ \\
\hline \multirow{5}{*}{$\begin{array}{l}\text { C. brachygona } \\
\mathrm{n}=24\end{array}$} & & & 0.44 & & 0.22 \\
\hline & & & 0.58 & & 0.29 \\
\hline & & & & 0.86 & 0.22 \\
\hline & & & & 1.21 & 0.30 \\
\hline & & & & & $\mathrm{X}=0.26 \pm 0.04$ \\
\hline \multirow{5}{*}{$\begin{array}{l}\text { C. melagonium } \\
\mathrm{n}=18\end{array}$} & 0.93 & & & & 0.62 \\
\hline & 0.79 & & & & 0.53 \\
\hline & & 1.84 & & & 0.61 \\
\hline & & 1.62 & & & 0.54 \\
\hline & & & & & $\vec{X}=0.58 \pm 0.04$ \\
\hline
\end{tabular}


Comparison of $I_{\mathrm{f}}$ values for Chaetomorpha species (Fig. 16) permitted extrapolation of their DNA contents. As specimens examined included both $3 \mathrm{X}$ and $4 \mathrm{X}$ chromosome complements, nuclear DNA contents were standardized to the $2 \mathrm{C}$ level of haploid ( $2 \mathrm{X}=$ $2 \mathrm{~N}=12$ ) genomes (Table 3). Results indicate similar values of 0.20 and $0.26 \mathrm{pg}$ DNA for C. aerea and C. brachygona, respectively, and 0.53 and $0.58 \mathrm{pg}$ for $C$. antennina and $C$. melagonium, respectively (Table 3). Thus, haploid nuclear genomes in the latter species contain approximately twice the nuclear DNA of the former species. Derived nuclear DNA contents for the Chaetomorpha species in the present study are within the range of values reported for related multinucleate green algae: Cladophora sericea (Huds.) Kütz. $=0.31 \mathrm{pg}$ and C. rupestris (L.) Kütz. $=0.32 \mathrm{pg}$ (Bot et al., 1989a), C. albida isolates $=0.8$ and $0.7 \mathrm{pg}$ (Bot et al., 1989b), and Dictyosphaeria cavernosa (Forssk.) Børg. $=1.79 \mathrm{pg}$ (Olsen et al., 1986).

\section{DISCUSSION}

Results of the cytophotometric investigation of four Chaetomorpha species indicate a correlation between plant habit (cell dimensions) and genome size. Both $C$. brachygona and $C$. aerea, with small diameter filaments $(<100 \mu \mathrm{m})$ have haploid genomes $(2 \mathrm{X}=2 \mathrm{~N}$ $=12$ ) approximately half as large as those of $C$. antennina and $C$. melagonium with filament diameters $>400 \mu \mathrm{m}$. A similar correlation between genome size and plant habit (cell dimensions) has been reported in Cladophora (Kapraun \& Gargiulo, 1987a, 1987b).

This relationship is of particular interest in multinucleate algae because of their potential to maintain an optimal ratio between genome content per cell and cell size by an increase in either the number of nuclei per cell or nuclear genome size (Goff \& Coleman, 1984, 1986). Although no attempt was made at quantification in the present study, microscopic examination of whole cell preparations following aceto-orcein staining suggested similar numbers of nuclei per cell in the four species studied. Consequently, the well-documented correlation in vascular plants between nuclear volume (genome size) and cell parameters including cell size and duration of mitosis and meiosis (Price \& Bachmann, 1975; Bennett, 1976; Bachmann et al., 1985) seems to apply equally to these multinucleate green algae.

It is tempting to speculate that in the Cladophorales, increased numbers of small nuclei would not provide a genome dose per cell equivalent to fewer large nuclei because of the qualitative difference between large and small genomes in related taxa. Specifically, large nuclear genomes are associated with proportionately greater amounts of repetitive DNA and/or heterochromatin (Rees \& Jones, 1972; Narayan \& Rees, 1976; Narayan, 1983; Ohri \& Khoshoo, 1986). In the present study, conspicuous heterochromatin contents were indicated for the two species with the largest cell dimensions, $C$. antennina and $C$. melagonium. Similarly, reassociation kinetics have demonstrated a significant repetitive component $(64-75 \%)$ in two species of Cladophora with relatively large nuclear genomes (Bot et al., 1989a, 1989b).

In the present study, chromosome numbers of 12,18 and 24 in four species of Chaetomorpha provide additional evidence of a polyploid series in this genus (Sarma, 1983). Although small chromosome size often prevented a precise determination of centromere positions, homologous pairing of straight and curved chromosomes suggests the presence of equal numbers of median and submedian centromeres (Figs 11 and 13). In addition, estimates of nuclear DNA indicate a significant difference in genome sizes 
between species with small and large filament diameters. Thus, Chaetomorpha, and the closely related genus Cladophora (Wik-Sjöstedt, 1970; Kapraun \& Gargiulo, 1987a, 1987b), appear to share several karyological features:

(1) a uniformity of chromosome numbers consisting of a polyploid series with a basic genome complement of $\mathrm{X}=6$,

(2) a constant karyotype with equal numbers of median and submedian centromeres,

(3) differences in chromosome size resulting in the karyotype complement of one species appearing to be a reduced or enlarged version of that of another, and

(4) large-scale, discontinuous interspecific variation in nuclear DNA content.

Data from comparative studies of cytology, life history, cytokinesis and cell wall composition have been cited as evidence that the Siphonocladales and Cladophorales should be merged into one order (Hoek, 1981, 1984; Hoek et al., 1988), with Cladophorales Haeckel having priority (Papenfuss \& Chihara, 1975). In addition, immunological distance estimates suggest that the genus Cladophora is paraphyletic (Olsen-Stojkovich et al., 1986; Hoek et al., 1988) with different species ernerging in distant portions of the proposed phylogenetic tree. Such a scheme would seem to require that the unique set of karyological features enumerated above evolved independently following several divergence events.

Karyological studies on the Cladophorales are in closer agreement with results of a cladistic analysis of rRNA sequence data for these multinucleate green algae (Zechman et al., 1990). Phylogenetic distance (most parsimonious branch length) estimates segregated cladophoralean algae into several closely related groups: (1) Chaetomorpha and Cladophora (Cladophorales); (2) Anadyomene and Microdictyon; (3) Cladophoropsis, and (4) Dictyosphaeria. It seems significant that these groups apparently have different basic chromosome complements (Kapraun \& Breden, 1988).

Acknowledgements. The authors gratefully acknowledge financial support for this research from the National Science Foundation (BSR-RUI 88-17846). This paper is contribution No. 20 to the Center for Marine Science Research, UNC-Wilmington.

\section{LITERATURE CITED}

Bachmann, K., Chambers, K. L. \& Price, H. J., 1985. Genome size and natural selection, observations and experiments in plants. In: The evolution of genome size. Ed. by T. Cavalier-Smith. Wiley, New York, 267-276.

Bennett, M. D., 1976. DNA, latitude, and crop plant distribution. - Environ. exp. Bot. 16, 92-108.

Bennett, M. D. \& Smith, J. B., 1976. Nuclear DNA amounts in angiosperms. - Phil. Trans. R. Soc. Lond. 274, 227-274.

Blair, S. M., 1983. Taxonomic treatment of the Chaetomorpha and Rhizoclonium species (Cladophorales; Chlorophyta) in New England. - Rhodora 85, 175--211.

Bodenbender, S. \& Schnetter, R. 1990. Nuclear behavior during the life cycles of Chaetomorpha, Enodesmis and Struvea (Ulvophyceae, Chlorophyta) under culture conditions. - Crypt. Bot. 1, 340-354.

Bot, P. V. M., Holton, R. W., Stam, W. T. \& Hoek, C. van den, 1989a. Molecular divergence between North Atlantic and Indo-West Pacific Cladophora albida (Cladophorales, Chlorophyta) isolates as indicated by DNA-DNA hybridization. - Mar. Biol. 102, 307-313.

Bot, P. V. M., Stam, W. T., Boele-Bos, S. A., Hoek, C. van den \& Selden, W. van, $1989 \mathrm{~b}$. Biogeographic and phylogenetic studies in three North Atlantic species of Cladophora (Cladophorales, Chlorophyta) using DNA-DNA hybridization. - Phycologia 28, 159-168. 
Calderón-Sáenz, E. \& Schnetter, R., 1989. Life cycle and morphology of Bryopsidella ostreobiformis spec. nov. (Bryopsidaceae, Chlorophyta) from the Mediterranean, under culture conditions, with comments on the phylogeny of the Bryopsis/Derbesia complex. - Botanica Acta 102, 249-260.

Goff, L. J. \& Coleman, A. W., 1984. Elucidation of fertilization and development in a red alga by quantitative DNA microspectrofluorometry. - Devl Biol. 102, 173-194.

Goff, L. J. \& Coleman, A. W., 1986. A novel pattern of apical cell polyploidy, sequential polyploidy reduction and intercellular nuclear transfer in the red alga Polysiphonia. - Am. J. Bot. 73, 1109-1130.

Hartman, M., 1929. Untersuchungen über die Sexualität und den Generationswechsel von Chaetomorpha und Enteromorpha. - Ber. ital. bot. Ges. 47, 485 494.

Hoek, C. van den, 1981. Chlorophyta, morphology and classification. In: The biology of seaweeds. Ed. by C. S. Lobban \& M. J. Wynne. Blackwell, Oxford, 86-132.

Hoek, C. van den, 1984. The systematics of the Cladophorales. In: The systematics of the green algae. Ed. by D. E. G. Irvine \& D. M. John. Acad. Press, New York, 157-178.

Hoek, C. van den, Stam, W. T. \& Olsen, J. L., 1988. The emergence of a new chlorophytan system, and Dr. Kornmann's contribution thereto. - Helgoländer Meeresunters, 42, 339-383.

Kapraun, D. F. \& Bailey, J. C., 1989. Karyology and nuclear DNA content of Gelidium pusillum (Gelidiales, Rhodophyta) from North Carolina, USA. - Jap. J. Phycol. 37, 201-207.

Kapraun, D. F. \& Breden, P. C., 1988. Karyological studies of Cladophoropsis (Siphonocladales, Chlorophyta) from Bermuda. - Botanica mar. 31, 515-520.

Kapraun, D. F. \& Dutcher, J. A., 1991. Cytophotometric estimation of inter- and intraspecific nuclear DNA content variation in Gracilaria and Gracilariopsis (Gracilariales, Rhodophyta). - Botanica mar. 34, 139-144.

Kapraun, D. F. \& Freshwater, D. W., 1987. Karyological studies of five species in the genus Porphyra (Bangiales, Rhodophyta) from the North Atlantic and Mediterranean. - Phycologia 26, 82-87.

Kapraun, D. F. \& Gargiulo, G. M., 1987a. Karyological studies of four species of Cladophora (Cladophorales, Chlorophyta) from coastal North Carolina. - Ital. J. Bot. 121, 1-26.

Kapraun, D. F. \& Gargiulo, G. M., 1987b. Karyological studies of three species of Cladophora (Cladophorales, Chlorophyta) from Bermuda. - Ital. J. Bot. 121, 165-176.

Kapraun, D. F. \& Martin, D. J., 1987. Karyological studies of three species of Codium (Codiales, Chlorophyta) from coastal North Carolina. - Phycologia 26, 228-234.

Kapraun, D. F. \& Shipley, M. J., 1990. Karyology and nuclear DNA quantification in Bryopsis (Codiales, Chlorophyta) from North Carolina, USA. - Phycologia 29, 443-453.

Kapraun, D. F., Gargiulo, G.M. \& Tripodi, G., 1988. Nuclear DNA and karyotype variation in species of Codium (Codiales, Chlorophyta) from the North Atlantic. - Phycologia 27, 273-282.

Kornmann, P., 1968. Das Wachstum einer Chaetomorpha-Art von List/Sylt. - Helgoländer Meeresunters. $18,194-207$.

Narayan, R. K. J., 1983. Chromosome changes in the evolution of Lathyrus species. In: Kew chromosome conference II. Ed. by P. E. Brandham \& M. D. Bennett. Allen \& Unwin, London, $243-250$.

Narayan, R. K. J. \& Rees, H., 1976. Nuclear variation in Lathyrus. - Chromosoma 54, 141-154.

Ohri, D. \& Khoshoo, T. N., 1986. Plant DNA, contents and systematics. In: DNA systematics. Ed. by S. K. Dutta. CRC Press, Boca Raton, Fla., 2-19.

Olsen-Stojkovich, J., West, J. A. \& Lowenstein, J. M, 1986. Phylogenetics and biogeography in the Cladophorales complex (Chlorophyta). Some insights from immunological distance data. Botanica mar. 29, 239-249.

Papenfuss, G. F. \& Chihara, M., 1975. The morphology and systematic position of the green algae Ernodesmis and Apjohnia. - Phycologia 14, 309-316.

Patel, R., 1971. Cytotaxonomical studies on Chaetomorpha I. Chaetomorpha linum (Muell) Kütz. and C. aerea (Dillw.) Kütz. - Phykos 11, 17-22.

Price, H. J. \& Bachman, K., 1975. DNA content and evolution in the Microseridinae. - Am. J. Bot. 62, 262-267.

Rees, H. \& Jones, R. N., 1972. The origin of the wide species variation in nuclear DNA content. - Int. Rev. Cytol. 32, 53-92.

Sarma, Y. S. R. K., 1983. Algal karyology and evolutionary trends. In: Chromosomes in evolution of eukaryotic groups. Ed. by A. K. Sharma \& A. Sharma. CRC Press, Boca Raton, Fla., 177-224. 
Sinha, J. P., 1958. Chromosome numbers and life cycles in members of Cladophorales. - Br. phycol. J. 1, 24-27.

Sinha, J. P., 1967. Cytotaxonomical studies on Cladophora glomerata, four freshwater forms. Cytologia 32, 507-518.

Taylor, W. R., 1960. Marine algae of the eastern tropical and subtropical coasts of the Americas. University of Michigan Press, Ann Arbor, $870 \mathrm{pp}$.

Wik-Sjöstedt, A., 1970. Cytogenetic investigations in Cladophora. - Hereditas 66, 233-262.

Wik-Sjöstedt, A. \& Nordquist, T., 1970. Preliminary observations on the ultrastructure of some Cladophora and Spongomorpha species. - Botanica mar. 13, 6-12.

Wynne, M. J., 1986. A checklist of benthic marine algae of the tropical and subtropical western Atlantic. - Can. J. Bot. 64, 2239-2281.

Zechman, F. W., Theriot, E. C., Zimmer, E. A. \& Chapman, R. L., 1990. Phylogeny of the Ulvophyceae (Chlorophyta): Cladistic analysis of nuclear-encoded rRNA sequence data. - J. Phycol. 26 , $700-710$. 